\title{
HAND-ASSISTED LAPAROSCOPIC LIVE DONOR NEPHRECTOMY - RIGHT-SIDED APPROACH: EXPERIENCE ATTAINED IN 38 CASES
}

\author{
Nefrectomia laparoscópica assistida direita em doador vivo: experiência com 38 casos
}

\begin{abstract}
Rafael Fábio Maciel, Ildefonso Rodrigues dos Santos, Fabio Gomes de Medeiros, José Abílio Oliveira Neto, José Eduardo Lopes, José Carlos Bouçanova, Willna Lola Vilar, Keyla FSC Felipe e Lúcia Vila Nova
\end{abstract}

\begin{abstract}
Removal of a donor kidney by laparoscopic nephrectomy is a safe method that is widely being used mainly in left donor nephrectomy. However, in right donor nephrectomy wherever the right renal vein is too short, the open surgery has been more frequently described in the literature. Purpose: To describe our experience in 38 renal transplants using two different techniques in right donor nephrectomy. Method: From February 2002 to May 2009, 38 hand-assisted laparoscopic right donor nephrectomies were performed. Twenty-five of these laparoscopic nephrectomies were performed by the method with the assistant using his hand to assist the surgery, and 13 nephrectomies were performed by the laparoscopic method assisted by the first surgeon. Results: Right donor nephrectomies assisted either by the hand of the assistant or the surgeon had similar results. All recipients had diuresis in the immediate post-operative period and the one week after the transplantation serum creatinine level was found to be $1.90 \mathrm{mg} / \mathrm{dl}( \pm 1.55)$. Conclusion: Although the hand techniques are similar, we concluded that the laparoscopic nephrectomy assisted by the surgeon is more adequate for the right kidney extraction. It can be performed either by a resident doctor or a surgeon from the transplantation team whether experienced or not in nephrectomy for transplantation.
\end{abstract}

Keywords: Kidney Transplantation, Laparoscopy, Treatment Outcome.

Instituição:

Departamento de Transplantes da Casa de Saúde Santa Efigênia - Caruaru / PE - Brasil

Correspondência:

Rafael Fábio Maciel

Rua Vasco Fernandes Coutinho, 47 - Caruaru / PE - CEP: 55014-360 - Brasil

Tel.: (81) 37190294

E-mail:rfmaciel@uol.com.br

Recebido em: 18.05 .2009

\section{INTRODUCTION}

The removal of a donor kidney by laparoscopic nephrectomy is a safe method which has been widely used for kidney transplantation, mainly for left kidney donors. However, for the right donor nephrectomy the traditional open surgery has been rather used and more frequently described in the literature..$^{1-5}$

Regardless the difficulty to perform the right nephrectomy due to the short right renal vein added to the difficulty in performing the graft implant, the assessment of the kidney extraction must follow the principle where the best kidney should always remain with the donor. In our transplantation center and as the purpose of this essay, the laparoscopic method has been indicated regardless the side. ${ }^{6-8}$

\section{PURPOSE}

To describe our experience in renal transplantation with 38 handassisted laparoscopic nephrectomies in right kidney donors, using two different handling methods.

\section{METHOD}

In the period ranging from February 2002 to June 2009, 38 right donor nephrectomies were performed in our center. Twenty five nephrectomies were performed using the laparoscopic method where the subordinate doctor used his hand to assist the surgery, and 13 assisted by the operative surgeon. 


\section{Hand-assisted Laparoscopic Nephrectomy assisted by the subordinate (HALDN/assistant):}

The hand-assisted laparoscopic live donor nephroureterectomy is performed under general anesthesia with the patient positioned with the torso 45 degree in a lateral decubitus position. A right lower quadrant abdominal incision of 6 to $8 \mathrm{~cm}$ length is transversally performed, then the distal ureter is mobilized and the hand-assist device is placed. A periumbilical incision is made to place a $10 \mathrm{~mm}$ camera port. Pneumoperitonium is created by the assistant surgeon via the hand-assist device and two additional ports of $10 \mathrm{~mm}$ are placed, one just below the xiphoid and one at the right flank. Another $5 \mathrm{~mm}$ trocar is placed at the subcoastal area to retract the liver. The parietocolic gutter is then dissected with the helping hand and an ultrasonic or electric scalpel, and at the same time the ureter mobilization is completed. Kidney is dissected until it is fixed only by the hilar vessels. The artery and vein are double ligated with "hem-o-lok" XLarge(XL) and Large(L) polymer clips, respectively. Once the renal vessels branches have been divided, the kidney graft is then retrieved, and the ureter is divided under direct sight.

\section{Hand-assisted Laparoscopic Nephrectomy assisted by the operative surgeon (HALDN/surgeon):}

In this method, the operating surgeon's hand is inserted into the abdomen via the hand-assist device. The ports are limited to two: one $10 \mathrm{~mm}$ port over the xiphoid, and another $5 \mathrm{~mm}$ port in the right flank used to retract the liver. All dissection is performed when the surgeon places his hand through the hand-assistant device, providing tactile sensation tracing and retracting the structures while the other is used to manipulate the trocars, clippers and ultrasonic or electric scalpel. In the same manner as the previous model the veins are double clipped with "hem-o-lok" polymer clips.

\section{RESULTS}

The general features of patients who underwent the laparoscopic nephrectomy for kidney donation are presented in Table 1.

Right laparoscopic donor nephrectomy performed by the assistant was executed in 38 patients, and the method where the operating surgeon used his left hand to assist the kidney extraction in 13 patients. Results regarding the operation time, transfusion requirement, warm ischemia time, recipient's immediate postoperative diuresis and complications were satisfactory in both methods (Table 2).

As to the graft function, the serum creatinine at discharge (one or two weeks) was satisfactory: after the seventh day of the immediate postoperative period the serum creatinine attained a mean level of $1.90 \mathrm{mg} / \mathrm{dl}( \pm 1.55)$, and in the second week $1.77 \mathrm{mg} / \mathrm{dl}( \pm 1.24)$, and no difference was found in both techniques.

\section{DISCUSSION}

Although the laparoscopic nephrectomy attains more space regarding to the kidney transplantation with living donor, there
Table 1. Patient's general characteristics

\begin{tabular}{lc}
\hline & Total. \\
\hline Amount of patients & 38 \\
Age ( mean) & $38,25(19-67)$ \\
Sex ( M/F) & $45,8 \% / 54,2 \%$ \\
$\operatorname{HLA}^{*}(\mathrm{D}-\mathrm{H}-\mathrm{I}) \%$ & $24 \%-60 \%-26 \%$ \\
\hline
\end{tabular}

*Human Leukocyte Antigen

Table 2. Operation time, blood loss, warm ischemia, recipient's immediate postoperative diuresis and complications by hand-assisted method

\begin{tabular}{|c|c|c|c|c|}
\hline & & HALDN/assistant & HALDN/surgeon & $\mathbf{p}$ \\
\hline Amount of Patients & & 25 & 13 & \\
\hline Operation Time & & $121 \min .(55-210)$ & $110 \min .(90-160)$ & NS \\
\hline Blood loss & & $110 \mathrm{ml}(30-700)$ & 120 ml (100-150) & NS \\
\hline Warm ischemia & & 210 sec. $(90-660)$ & $180 \mathrm{sec} .(60-210)$ & NS \\
\hline \multicolumn{5}{|c|}{ Recipient Diuresis (mean) PO: } \\
\hline & 1st day & $5483 \mathrm{ml}$ & $6255 \mathrm{ml}$ & NS \\
\hline & 3rd day & $4011 \mathrm{ml}$ & $3800 \mathrm{ml}$ & NS \\
\hline & 7th day & $3143 \mathrm{ml}$ & $3275 \mathrm{ml}$ & NS \\
\hline Complications & & None & None & \\
\hline
\end{tabular}

are few randomized controlled trials that have been devoted to the study of such technique and its results.

Nanidis TG et al met the criteria specified in 73 studies with 6,594 patients, and concluded that the laparoscopic surgery reduces the risks and increases the benefits. ${ }^{9}$ As to the costs, it has been observed that due to the lower hospitalization rate associated to the soon return to labor activities and the aesthetic result show a difference in the advantages compared to the open surgery. ${ }^{10}$ It offers less aggression to tissues, brings more comfort, better aesthetic results and return to work in two or three weeks, without changing the transplantation outcomes such as: technical implant conditions, immediate diuresis, and drop of the creatinine levels.

\section{CONCLUSION}

Both techniques have presented similar results for recipient and donor. However, it's understood that the technique where the surgeon used the intra-corporeal hand (HALDN/surgeon) to manually assist in the dissection and vessels ligature is more suitable for the right kidney. The digital palpation is a valuable tool that provides the surgeon a tactile sensation to manually trace the vascular structures, especially of the aorta and renal artery. The coordination between the surgeon and the assistant team is essential and a key to this method, requiring that both have experience in advanced laparoscopic surgery. We concluded that the hand-assisted laparoscopic nephrectomy assisted by the surgeon is more adequate for the right kidney extraction. It can be performed either by a resident doctor or surgeon whether experienced or not in nephrectomy for transplantation. 


\section{RESUMO}

A nefrectomia laparoscópica para retirada de rim de doador vivo para transplante é um método seguro amplamente utilizado em retiradas de rim, principalmente à esquerda. À direita, onde a veia é curta, a cirurgia aberta tem sido mais freqüentemente relatada na literatura. Objetivo: Relatar experiência em transplante renal em 38 nefrectomias laparoscópicas de rim direito assistidas com a mão, utilizando-se dois tipos de manejo técnico. Método: No período de fevereiro 2002 a maio de 2009 foram realizadas 38 nefrectomias laparoscópicas assistidas de rim direito, sendo vinte e cinco pelo método laparoscópico assistido com a mão do auxiliar e 13 pelo método laparoscópico assistido pela mão do $1^{\circ}$ cirurgião. Resultado: A assistência pela mão do auxiliar ou pela mão do cirurgião nas nefrectomias de rim direito teve resultado semelhante. Todos os receptores apresentaram diurese imediata e em uma semana apresentavam creatinina média de 1,90mg/ dl $(+1,55)$. Conclusão: As técnicas equivalem-se, porém, acreditamos que aquela em que o cirurgião introduz a sua mão é mais adequada para o rim direito. Pode ser executada com auxilio do médico residente ou cirurgião da equipe com ou sem experiência em nefrectomias para transplante.

Descritores: Transplante Renal, Laparoscopia, Resultado de Tratamento.

\section{REFERENCES}

1. Bettschart V, Boubaker A, Martinet O, Golshayan D, Wauters JP, Mosimann F. Laparoscopic right nephrectomy for live kidney donation: functional results. Transpl Int. 2003;16(6):419-24.

2. Mateo RB, Sher L, Jabbour N, Singh G, Chan L, Selby RR, et al. Comparison of outcomes in noncomplicated and in higher-risk donors after standard versus handassisted laparoscopic nephrectomy. Am Surg. 2003;69(9):771-8.

3. Boorjian S, Munver R, Sosa RE, Del Pizzo JJ. Right laparoscopic live donor nephrectomy: a single institution experience. Transplantation. 2004;77(3):437-40.

4. Wang DS, Bird VG, Winfield HN, Rayhill S. Hand-assisted laparoscopic right donor nephrectomy: surgical technique. J Endourol. 2004;18(3):205-09; discussion 209-10.

5. Posselt AM, Mahanty H, Kang SM, Stoller ML, Meng MV, Roberts JP, et al. Laparoscopic right donor nephrectomy: a large single-center experience. Transplantation. 2004;78(11):1665-9.
6. Maciel RF, Branco AJ, Branco AW, Guterres JC, Silva AE, Ramos LB, et al. Renal artery aneurysm in hand-assisted laparoscopic donor nephrectomy: case report. Transplant Proc. 2003;35(8):2858-9.

7. Maciel RF, Deboni LM, Vieira JA, et al. Abordagem dos vasos renais sem grampeador na nefrectomia laparoscópica para doador vivo assistida com a mão. Jornal Brasileiro de Transplantes. 2004;7(2):72.

8. Branco AWBF, Alcides J, Kondo W; George MA, Carvalho RM, Maciel RF. Maximizing the right renal vein length in laparoscopic live donor nephrectomy. International braz j urol. 2004;30(5):416-19.

9. Nanidis TG, Antcliffe D, Kokkinos C et al. Laparoscopic versus open live donor nephrectomy in renal transplantation: a meta-analysis. Ann Surg. 2008; 247: 58-70.

10. Lotan Y, Duchene DA, Cadeddu JA, Koeneman KS. Cost comparison of hand assisted laparoscopic nephrectomy and open nephrectomy: analysis of individual parameters. J Urol 2003;170(3):752-5. 